\title{
Digitalisasi Aktivitas Jual Beli di Masyarakat: Perspektif Teori Perubahan Sosial
}

\author{
Laily Bunga Rahayu ${ }^{1}$, Nur Syam ${ }^{2}$ \\ ${ }^{12}$ UIN Sunan Ampel Surabaya \\ ${ }^{1}$ layrabunga@gmail.com, ${ }^{2}$ nursyamtuban2018@gmail.com
}

\begin{tabular}{l}
\hline Keywords: \\
\hline Social Change, \\
Buying and \\
Selling Activities, \\
Digitalization \\
\hline
\end{tabular}

Kata Kunci:

Perubahan Sosial, Aktivitas Jual Beli, Digitalisasi

\begin{abstract}
This study discusses buying and selling activities in the present context. A process of changing buying and selling activities that were originally traditional or conventional to digital. Due to the rapid development of technology, it is finally making changes to buying and selling activities that were originally by way of direct transactions face to face between sellers and buyers, now sellers and buyers only transact via virtual or online using certain platforms. This study uses a qualitative research method, where the researcher aims to describe and analyze changes in people's behavior related to buying and selling activities from an offline system to an online one. Social change in society is not a result or a product but a process. This change process is of course the result of an agreement or joint decision taken by an individual or a community group. The decisions taken are of course in accordance with the wishes or expectations of the group so that social change can be realized.
\end{abstract}

\begin{tabular}{l} 
Abstrak \\
\hline Penelitian ini membahas aktivitas jual beli dalam konteks \\
kekinian. Suatu proses perubahan aktivitas jual beli yang \\
mulanya secara tradisional atau konvensional menjadi digital. \\
Karena perkembangan teknologi yang begitu pesat tersebutlah \\
yang akhirnya membuat perubahan adanya aktivitas jual beli \\
yang mulanya dengan cara bertransaksi secara langsung bertatap \\
muka antar penjual dan pembeli, kini para penjual dan pembeli \\
hanya bertransaksi melalui virtual atau online dengan \\
menggunakan platform tertentu. Penelitian ini menggunakan \\
metode penelitian kualitatif, dimana peneliti bertujuan untuk \\
mendeskripsikan dan menganalisa perubahan perilaku \\
masyarakat terkait aktivitas jual beli dari system offline menjadi \\
serba online. Perubahan sosial dalam masyarakat bukan \\
merupakan hasil atau produk melainkan suatu proses. Proses \\
perubahan ini tentu saja merupakan hasil dari suatu kesepakatan \\
atau keputusan bersama yang diambil oleh individu atau suatu
\end{tabular}


kelompok masyarakat. Keputusan yang diambil tentu saja yang sesuai dengan keinginan atau harapan kelompok agar perubahan sosial dapat terwujud.

\section{Pendahuluan}

Modernisasi pada zaman sekarang ini bagaikan laju lokomotif yang tidak dapat terbendung lagi. Modernisasi tidak hanya dalam lingkup aspek tertentu dalam kehidupan, tetapi semua aspek mengalami suatu perubahan, seperti misalnya modernisasi dalam bidang sosial, pendidikan, hukum, dan lain sebagainya. Istilah modernisasi dianggap sebagai adanya suatu proses proses perubahan dari konvensional menuju kemodernan. Perubahan menuju modern ini tidak hanya dapat dilihat dari aspek-aspek baru dalam kehidupan, tetapi aspek-aspek lamapun juga ikut tergerus arus modernisasi. Salah satu aspek yang tergerus oleh arus modernasasi adalah aktivitas jual beli yang terjadi di masyarakat. Jual beli (bisnis) di masyarakat merupakan kegiatan rutinitas yang dilakukan setiap waktu oleh semua manusia (Shobirin, 2015). Dalam kehidupan modern seperti saat ini, persaingan jual beli tidak hanya dikarenakan lokasi took yang bersebelahan satu sama lain, melainkan banyak lagi tantangan lainnya yang lebih kompleks.

Untuk mengatasi persaingan di zaman modern ini, aktivitas jual beli di masyarakat perlu adanya inovasi. Tidak dapat dipungkiri bahwa adanya inovasi yang dilakukan oleh masyarakat maupun pemerintah pada proses jual beli akan berakibat terjadinya perubahan sosial. Dalam proses inovasi pada proses jual beli tersebut, teknologi adalah salah satu aspek yang ditekankan dalam pengembangan atau kemajuan penjualam. Secara umum, teknologi adalah sarana untuk mencapai tujuan demi kelangsungan dan kenyamanan hidup masyarakat. Secara sosiologis, teknologi bukan berarti sama dengan permesinan seperti dalam pemahaman umum lainnya. Dalam bahasan sosiologi, teknologi mencangkup semua teknik produktif, seperti perangkat keras dalam berproduksi, managemen kerja, maupun organisasi kerja (Nur Indah Ariyani, 2014).

Teknologi merupakan suatu alat yang dapat membantu untuk mengetahui bagaimana cara menghasilkan produk-produk yang dikehendaki, meminimalisir suatu permasalahan. Teknologi modern juga mampu mengurangi hambatan berinteraksi dalam kehidupan masyarakat. Dari bangkitnya kemampuan teknologi tersebut, melahirkan adanya sub-sub sosial maupun budaya. Tetapi tidak dipungkiri pula bahwa keberadaan teknologi baru (modern) juga mengakibatkan efek negatif dalam beberapa aspek lainnya. 
Karena perkembangan teknologi yang begitu pesat tersebutlah yang akhirnya membuat perubahan adanya aktivitas jual beli yang mulanya dengan cara bertransaksi secara langsung bertatap muka antar penjual dan pembeli, kini para penjual dan pembeli hanya bertransaksi melalui virtual atau online dengan menggunakan platform tertentu. Di era revolusi industry 4.0 ini telah mengubah tatanan system perindustrian dari teknologi yang berkembang pesat menjadi teknologi digital. Baik dari segi transportasi, perdagangan, maupun perbankan. Mau tidak mau semua system bisnis yang masih menerapkan konvensional beralih pada digital. Perdagangan pada era digital sudah tidak mengenal batas negara, maupun waktu. Bisa melakukan transaksi tanpa berpindah tempat dan dalam waktu yang lebih efisien dan menghemat biaya. Contoh menjamurnya taksi online, jual beli online dan kegiatan yang memanfaatkan teknologi daring (Editor, 2018). Belanja dengan system online merupakan salah satu gaya hidup dan bermetmorfosa menjadi budaya popular yang dilakukan banyak orang di masyarakat Indonesia. Sejak perkembangan internet meningkat, sebagian besar aktivitas pun dilakukan dengan lebih instan. Belanja pun lebih praktis. Konsumen tinggal pesan, transfer, dan barang pun bisa sampai di rumah. Tidak jarang harga barang di took online lebih murah daripada di took offline. Hal ini dikarenakan took online tidak memerlukan biaya operasional yang besar (Rozi, 2020).

Hal tersebutlah yang akhirnya menjadikan terjadinya perubahan sosial. Dalam perspektif sosiologi, perubahan sosial dipahami sebagai proses. Artinya perubahan sosial akan selalu terjadi sepanjang masa mengingat masyarakat pun terus bergerak, berkembang, dan berubah. Setiap individu atau kelompok dalam masyarakat pasti akan mengalami suatu perubahan. Hal ini terjadi karena setiap individu dan anggota kelompok masyarakat tersebut memiliki pemikiran dan kemampuan untuk terus berkembang dari waktu ke waktu. Seringkali perubahan yang terjadi di masyarakat karena adanya unsurunsur yang harus dilakukan dalam mencapai kehidupan yang lebih layak di masa depan. Perubahan ini dipicu oleh keinginan untuk menjalankan kehidupan yang lebih baik. Selain itu, hakikat dan sifat manusia yang selalu ingin membuat perubahan terus menciptakan hal baru. Seiring berjalannya waktu, hal-hal baru terus berkembang hingga akhirnya mengubah system yang lama (Prinada, 2021). 


\section{Metode}

Penelitian ini menggunakan jenis penelitian kualitatif. Metodologi kualitatif ialah prosedur penelitian yang menghasilkan data deskriptif berupa kata-kata tertulis atau lisan dari orang-orang dan perilaku yang diamati (Pradoko, 2017). Dimana peneliti bertujuan untuk mendeskripsikan dan menganalisa perubahan perilaku masyarakat terkait aktivitas jual beli dari system offline menjadi serba online. Untuk menghasilkan data yang kongkrit, penulis akan melakukan studi kepustakaan dan analisa (Sumarno Adi Subrata, 2017). Studi kepustakaan dilakukan dengan cara menggali informasi yang didapat dari berbagai sumber baik itu dari buku, artikel, jurnal maupun blog. Setelah melakukan studi kepustaakaan, kemudian dilakukan analisa guna mencari makna dan jawaban yang tepat terkait digitalisasi aktivitas jual beli yang terjadi di masyarakat saat ini. Analisa yang digunakan dalam penelitian ini ialah menggunakan paradigma teori perubahan sosial. Perubahan sosial menuntut terjadinya penyesuaian dalam konsepsi model komunikasi karena masing-masing elemen dalam komponen pemangku kepentingan komunikasi mengalami pergeseran peran dan posisi. Perubahan merupakan proses yang terus menerus terjadi dalam setiap masyarakat (Nur Indah Ariyani, 2014).

\section{Hasil dan Pembahasan}

\section{Aktivitas Jual Beli}

Jual beli (Al-ba'i) menurut Bahasa artinya menjual, mengganti, dan menukar sesuatu dengan sesuatu yang lain. Kata $a l-b a$ 'I merupakan sebuah kata yang mencakup pengertian dari kebalikannya yakni al-syira' (membeli). Dengan demikian kata al-ba'I disamping bermakna kata jual juga sekaligus kata beli. Adapun pengertiab jual beli menurut istilah (terminology) yaitu tukar menukar barang dengan barang atau barang dengan uang yang dilakukan dengan jalan melepaskan hak milik dari yang satu kepada yang lain atas dasar sukarela. Adapun jual beli menurut Syaikh Al-Qayubi dalam Hasyiyah-nya yaitu jual beli merupakan akad saling mengganti dengan harta dengan berakibat kepada kepemilikan terhadap suatu benda atau manfaat untuk tempo waktu selamanya (Yanti, 2018).

Ada juga Sayyid Sabiq dalam kitabnya Fiqh Sunnah yang mengartikan jual beli yaitu penukaran benda dengan benda lain dengan jalan saling atau memindahkan hak milik denga nada penggantinya dengan cara yang diperbolehkan. Menurut Imam Taqiyyudin dalam kitab Kiffayatul Akhyar yakni saling tukar harta, saling menerima, 
dapat dikelola (tasharruf) dengan ijab qobul, dan dengan cara yang sesuai dengan syara (Susiawati, 2017).

Dari beberapa pengertian tersebut diatas maka dapat dipahami bahwasanya aktivitas jual beli merupakan suatu interaksi sosial antar manusia yang berdasarkan rukun dan syarat yang telah ditentukan. Jual beli diartikan "al-bai', al tijarah, dan al mubadalah”. Pada intinya jual beli merupakan suatu perjanjian tukar menukar barang atau benda yang memiliki manfaat untuk penggunanya, kedua belah pihak telah menyepakati perjanjian yang telah dibuat dengan saling suka rela.

\section{Peran Teknologi dalam Perkembangan Manusia}

Teknologi telah menunjukkan peranannya dlam kehidupan manusia. Berkat teknologi banyak aspek kehidupan manusia dapat dipermudah, baik aspek social, aspek ekonomi, aspek politik dan berbagai macam aspek dalam kehidupan manusia. Adanya teknologi juga dapat mempermudah manusia dalam mengakses informasi. Banyak lagi kemudahan - kemudahan yang diperoleh manusia dari produk-produk teknologi.

Menurut Martin Heidegger telah mempertanyakan fenomena teknologi sebagai masalah filsafat. Heidegger mengartikan teknologi sebagai suatu bentuk keberadaan di dunia, yang mencerminkan manusia tercekam dalam keinginan untuk selalu memperbesar kelengkapan serta kemudahan baginya terhadap alam dalam rangka menjamin eksistensinya. Dengan demikian teknologi membentuk relasi yang ditandai dengan hasrat mengeksploitasi alam sejauh dan seefesien mungkin.hal ini berarti menunjukkan perubahan sikap manusia terhadap alamnya yang semula ditentukan oleh nilai kualitatif menjadi hubungan produksi yang dapat dikuatitatifkan (Nur Indah Ariyani, 2014).

\section{Teori Perubahan Sosial}

Pembahasan dalam kajian ini ialah terkait terjadinya perubahan sosial berkaitan dengan adopsi teknologi komunikasi. Perubahan sosial menuntut terjadinya penyesuaian dalam konsepsi model komunikasi karena masing-masing elemen dalam komponen pemangku kepentingan komunikasi mengalami pergeseran peran dan posisi. Perubahan merupakan proses yang terus menerus terjadi dalam setiap masyarakat. Proses perubahan itu ada yang berjalan sedemikian rupa sehingga tidak terasa oleh mayarakat pendukungnya. Gerak perubahan yang sedemikian itu disebut evolusi. Sosiologi mempunyai gambaran adanya perubahan evolusi masyarakat dari masyarakat sederhana 
ke dalam masyarakat modern. Proses gerak perubahan tersebut ada dalam satu rentang tujuan ke dalam masyarakat modern. Berangkat dari pemikiran teori evolusi Comte tentang perubahan sosial. Titik tolak pemikiran Comte adalah pandangannya tentang masyarakat dengan memanfaatkan konsep-konsep biologi, yang dapat diringkas.

Untuk memudahkan pemetaan dalam kajian ini dikelompokkan dua jenis riset ilmu komunikasi yaitu:

a. Studi yang menjelaskan fenomena sosial, politik, atau budaya dengan mengenalkan faktor-faktor komunikasi seperti pengaruh komunikasi, teknologi komunikasi atau perilaku komunikasi

b. Studi yang menjelaskan fenomena komunikasi atau masalah dengan menggunakan teori-teori terhadap masyarakat, politik, budaya, psikolog, atau komunikasi itu sendiri. Berkaitan dnegan perubahan sosial yang terjadi, pertanyaan akademis akan dijelaskan dalam penelitian ini menyangkut terjadinya perubahan sosial dari perspektif komunikasi (Budiyono, 2015).

Perubahan di Indonesia selalu dikaitkan dengan pembangunan ekonomi selain menyangkut proses pembangunan sosial dan budaya. Berkaitan dengan teknologi komunikasi, secara mendasar dipahami bahwa teknologi komunikasi itu menentukan wajah masyarakat. Informasi dan teknologi komunikasi yang sedang berkembang pesat telah mengubah lingkungan informasi mulai dari produksi massa informasi yang seragam menuju diversifikasi, berjenjang da $\mathrm{n}$ informasi yang terspesialisasikan.

Masyarakat kontemporer terlihat bertumbuh dalam sekat-sekat komunitas sebagaimana yang terjadi dalam jaringan media sosial. Jauh sebelumnya menurut Ito juga terjadi di negara-negara sosialis pada tahun-tahun terakhir dimana control aliran informasi oleh pemerintah sangat ketat, namun secara drastic terjadi perubahan dalam masyarakat. Komunikasi massa telah menciptakan mass society. Masyarakat baru setelah mass society telah menjadi lebih tresegmentasikan bukan oleh tanggal kelahiran atau profesi sebagaimana di masa lalu, melainkan dengan ideology, nilai-nilai, selera, dan gaya hidup. Pendeknya orang-orang dalam masyarakat informasi sangat kuat perhatiannya terhadap informasi, dimana kecenderungan ini telah mengubah masyarakat massa yang berbasiskan kepada komunikasi massa dan produksi massa menuju segmented society yang berbasiskan pada media baru dan mode produksi yang juga tersegmentasikan (Hidayat, 2015). 
Masyarakat berkembang seiring perkembangan teknologi yang menyertai zamannya. Kekuatan informasi dalam masyarakat maju merupakan sebuah indikator atas perubahan zaman. Dahlan memastikan bahwa informasi adalah dasar kekuasaan dalam masyarakat masa depan, seperti tanah di masyarakat pertanian, atau uang dan barang modal dalam masyarakat industri. Menurutnya, informasi memiliki kekuatan sehingga tidak dapat diberikan kepada produsen informasi melainkan dalam kepemilikan atau penerapan sumber daya informasi Pentingnya informasi yang terus berkembang tidak hanya dari segi ekonomi tetapi juga dalam konteks seluruh masyarakat pada umumnya. Daniel Bell juga menegaskan bahwa informasi adalah komoditas yang sangat dihargai dalam masyarakat informasi sehingga berdampak pada struktur sosial. Mereka yang menghasilkan informasi baru (ilmuwan, pekerja $\mathrm{R} \& \mathrm{D}$, insinyur) akan diperlakukan sebagai elit super dalam struktur kelas yang baru muncul. Informasi juga dianggap oleh Bell sebagai sumber daya strategis untuk transformasi masyarakat dalam segala aspek, termasuk politik. Bell mengatakan, - Saya akui saya tidak terpesona dengan cita-cita orang-orang yang berpikir bahwa keadaan normal manusia itu berjuang untuk mendapatkan dengan menginjak-injak, menghancurkan, menyikut, dan menginjak tumit masing-masing, untuk membentuk kehidupan social. Itulah hal yang paling diinginkan oleh banyak jenis manusia, atau apa pun. Kecuali gejala tidak menyenangkan dari salah satu fase kemajuan industry.

Informasi dan komunikasi merupakan elemen penting dalam pembentukan masyarakat: mereka menentukan karakteristik sosial. Masyarakat hanya dapat terbentuk ketika jaringan informasi terbentuk, dan kesepakatan dasar dan aturan ditetapkan pada apa, siapa, dan bagaimana berkomunikasi. Struktur informal sosial dan kelembagaan formal pada dasarnya adalah komunikasi dan jaringan informasi, pengelolaan informasi dan alirannya.

Menurut Weber, masalah kehidupan modern yang paling menentukan adalah perkembangan rasionalitas formal. Rasional formal yang dimaksudkan Weber, meliputi proses berfikir aktor dalam membuat pilihan mengenai alat dan tujuan. Dalam hal ini pilihan dibuat dengan merujuk pada kebiasaan, peraturan, dan hukum yang diterapkan secara universal. Ketiganya berasal dari berbagai struktur berskala besar, terutama struktur birokrasi dan ekonomi. Teknologi menyebabkan terjadinya perubahan sosial cepat yang sekarang melanda dunia. 
Perubahan teknologi akan lebih cepat dibanding dengan perubahan pada perubahan budaya, pemikiran, kepercayaan, nilai-nilai, norma-norma yang menjadi alat untuk mengatur kehidupan manusia. Oleh karena itu, perubahan seringkali menghasilkan kejutan sosial yang yang pada gilirannya akan memunculkan pola-pola perilaku baru, meskipun terjadi konflik dengan nilai-nilai tradisional (Nur Indah Ariyani, 2014).

\section{Realitas aktivitas Jual Beli dan Perubahannya}

Fenomena modernisasi terjadi di segala sendi kehidupan, termasuk dalam bidang ekonomi, dengan munculnya pasar digital selain pasar tradisional dan pasar modern. Perkembangan laju ekonomi ini mempunyai konsekuensi bagi para pelaku usaha di dalamnya. Di sisi lain, fenomena terkait merupakan gambaran dari kemampuan sumber daya manusia dalam kecakapan teknologi digital pada konteks usaha, yakni melahirkan rumus baru "literasi digital + ekonomi = pasar digital (realitas kedua)". Secara umum, pasar merupakan ranah atau medium terjadinya proses jual-beli, interaksi antara penjual dan pembeli, juga sebagai ranah perantara dalam pemenuhan kebutuhan kehidupan (Bagus Ardiansyah, Drajat Tri Kartono, 2019).

Fenomena ekonomi dengan kemunculan pasar digital tersebut dipengaruhi oleh perkembangan spat- kapitalisme (produksi kebutuhan semu). Laju perkembangan spatkapitalisme, budaya pascamodern, dan teknologi cyberspace hingga dewasa ini telah membawa masyarakat ke dalam beragam arus perubahan yang hipercepat. Arus perubahan hipercepat ini, ibaratnya adalah dunia yang terus berlari; tidak pernah mengurangi tempo produksi, konsumsi, dan kecepatan informasinya, sehingga membuat atau mengondisikan manusia tak bisa beristirahat sedikit pun.

Salah satu contoh produk dari dunia yang tak pernah berhenti berlari ini adalah internet. Melalui kemajuan informasi dan teknologi ini, manusia menjelma bahkan menandingi Tuhan dengan menguasai ruang, menguasai jarak, menguasai waktu, dan menciptakan tubuh virtual. Artinya, kini manusia seolah mempunyai kekuasaan atau kekuatan tak terbatas seperti Tuhan. Inilah citra penampakan spirit kapitalisme di dalam spirit pascamodernisme dan di dalam spirit cyberspace, sebuah dunia yang dikuasai oleh informasi atau penampakan digital.

Penetrasi dari angka pengguna internet tersebut ibarat tambang emas bagi aktor yang akan terjun ke e-commerce (pasar digital). Laju percepatan kenaikan pengguna internet ini, berimbas sampai ke ranah transaksi jual-beli, di mana masyarakat lebih 
memilih melakukan pembelian tidak lagi lewat pasar nyata, tetapi lewat pasar digital. Perubahan lanskap kehidupan sosial di era inovasi teknologi komputer dan komunikasi yang meningkatkan kemampuan manusia dalam memproduksi, mendistribusikan, dan mengonsumsi informasi secara masif lewat beragam media Inilah yang akhirnya menyebabkan menjamurnya toko-toko online yang ada di Indonesia, seperti Shopee, Lazada, Tokopedia, Blibli.com, Zalora, Bukalapak, dan lain sebagainya. Hal ini karena masyarakat lebih banyak menghabiskan waktunya untuk berselancar di internet, termasuk dalam bertransaksi online. Suatu gambaran terwujudnya apa yang diinginkan oleh pemerintah, yang mencanangkan Indonesia sebagai largest digital economy pada 2020 dan menargetkan menjadi yang terbesar di Asia Tenggara (Awy Apriani Ningrum Simamora, 2019).

Saat ini kegiatan jual beli tidak hanya dapat dilakukan dengan bertemu langsung. Teknologi digital membuat semua proses berjualan serta berbelanja menjadi lebih mudah dan praktis. Salah satu aktivitas jual beli yang banyak diminati saat ini ialah melalui $e$ commerce. E commerce sendiri berasal dari Bahasa Inggris yaitu electronic commerce atau perdagangan elektronik. Dan sebagaimana perdagangan yang dilakukan secara langsung atau face to face. Dalam e commerce juga meliputi proses promosi, pembelian, dan juga pemasaran produk. Yang membedakan ialah pada system berdagang yang digunakan, yakni melalui media elektronik atau internet.

Dalam e commerce, seluruh proses perdagangan mulai dari proses pemesanan produk, pertukaran data, hingga transfer dana dilakukan secara elektronik. Di tengah perkembangan arus teknologi dan informasi digital yang semakin canggih aktivitas $e$ commerce ialah suatu penerapan dari $e$ business atau bisnis elektronik yang mana berhubungan dengan kegiatan transaksi komersial (Nugroho, 2019).

e-commerce mengalami perkembangan yang pesat di Indonesia karena beberapa faktor yaitu adanya penetrasi smartphone dan internet yang terus mengalami peningkatan, jumlah penduduk Indonesia yang besar dan daya belinya meningkat di tengah pertumbuhan makroekonomi yang kuat, serta Indonesia memiliki populasi yang muda dan melek teknologi, artinya mereka dengan cepat menyesuaikan diri dengan teknologi baru (Nur Indah Ariyani, 2014).

Adapun beberapa cara perubahan aktivitas jual beli secara digital sebagai berikut: 
a. Melalui media sosial

Jual beli menggunakan media sosial saat ini sangat menguntungkan dengan banyaknya masyarakat Indonesia yang mengakses media sosial seperti facebook, Instagram, dan twitter. Namun demikian ada kelemahan mendasar yang membuat kegiatan jual beli lewat cara ini dianggap kurang begitu efektif mendongkrak pemasaran. Jual beli melalui media sosial memiliki kelemahan, yang pertama kelemahannya yakni kurang dipercaya oleh pembeli yang belum mengenal produk dan belum menjadi pedagang yang dipercaya oleh konsumen. Kelemahan kedua ialah manual dalam pencarian konsumen. Dalam arti kadang penjual tidak mngetahui siapa pembeli dan bagaimana menghadapi konsumen yang memberikan komentar negative terhadap produk yang dijualnya.

b. Melalui personal website

Banyak pelaku usaha yang pada akhirnya melakukan pemasaran menggunakan website atau blog pribadi khusus untuk merk dagangannya sendiri. Sisi positif dari penjualan melalui personal website ialah melihat sisi branding yang sangat positif karena bisa mendongkrak gengsi, pamor, dan penjualan bagi pemiliki website. Tapi kelemahannya penjual harus punya orang yang benar-benar bisa meluangkan waktu memonitor dan meningkatkan kualitas website tersebut. Effort (usahanaya) sangat besar, susah kalua punya website tapi tidak ada yang maintenance web dan tidak interaktif dengan pelanggan.

c. Melalui online shop

Ada dua jenis online shop yang berkembang di Indonesia:

1). Situs iklan baris

Online shop berbentuk situs iklan baris ialah jenis online shop yang hanya menyediakan platform berbentuk barisan produk yang ditawarkan pengiklan. Contohnya seperti lazada, mataharimall.com, zalora, dan sebagainya.

\section{2). Marketplace}

Marketplace merupakan situs jual beli online yang menawarkan layanan penjualan secara lengkap. Artinya kegiatan promosi hingga transaksi jual beli semuanya dilayani dengan system yang telah teruji. Situs jual beli berbentuk marketplace di Indonesia, contohnya ialah Lazada, Bukalapak, blibli, Tokopedia, Shopee, elevania, dan banyak lagi lainnya.

Perilaku pembelian online saat ini terdiri atas tiga hal: 
1) Visiting (search)

Calon pembeli pertama-tama mengakses situs e-commerce. Kunjungannya ini dilakukan setelah mengidentifikasi kebutuhan yang ingin dibeli. Namun ada juga yang hanya ingin sekedar meluangkan waktunya melihat-lihat produk, jasa atau promo yang ditawarkan pihak e-commerce.

2) Purchasing

Setelah seseorang melakukan kunjungan atau pencarian dan menemukan produk atau jasa yang cocok baginya, kemudian ia akan melakukan pembelian. Ada beberapa hal yang melatarbelakangi pembelian seseorang di situs e-commerce, pertama seseorang melakukan pembelian karena memang membutuhkan barang atau jasa tersebut. Kedua seseorang melakukan pembelian karena tertarik dengan promo yang ditawarkan penyedia layanan e-commerce.

3) Multi Channel Shopping

Ialah fitur yang disediakan oleh situs e-commerce dalam bentuk penyediaan berbagai macam jalur atau cara pembelian bagi konsumennya. Hal ini bertujuan untuk memaksimalkan nilai belanja konsumen. Konsumen yang akan membeli bisa membeli produk dengan cara yang disenanginya. Sebagai contoh yaitu pada e-commerce salestock, konsumen salestock bisa melakukan pembelian tidak hanya melalui website, tapi bisa juga melalui aplikasi di smartphone, whatapp, line, chat facebook, dan Instagram (Dedy Ansari Harahap, 2018).

Akhir-akhir ini belanja online semakin menjadi aktivitas yang digemari banyak kalangan. Apalagi di masa pesta belanja online yang biasanya merupakan momen yang sangat ditunggu banyak orang karena akan banyak promo besar-besaran dan penawaran bebas biaya pengiriman. Pada tahun 2018, total transaksi harbolnas 12.12 mencapai Rp 6,8 triliun. Pada tahun 2019 meningkat menjadi Rp 9,1 triliun (Editor, 2020).

Salah satu hasil penelitian juga menyampaikan bahwasanya terjadinya peningkatan belanja online pada ibu-ibu rumah tangga dengan alasan tergiur karena tawaran barang yang diiklankan apalagi dengan diskon harga barang yang semakin meningkat, semakin banyak barang yang dibeli, semakin banyak diskon-diskon yang terkadang disertai dengan gratis ongkir. Ada juga yang memilih berubah ke belanja online karena memang para penjual di marketplace atau di onlineshop tersebut banyak memberikan potongan harga bahkan cashback sampai dengan 50\% (Andi Maghfirah Juniar, 2021). 
Selain itu Chief Customer care officer marketplace lazada Indonesia juga menyampaikan bahwasanya data yang ia terima dari McKinsey sebanyak $57 \%$ masyarakat melakukan aktivitas perbelanjaan melalui digital (Catriana, 2020). Ada juga data yang dilansir dari twitter, percakapan tentang belanja meningkat sebanyak $60 \%$ pada Maret 2020. Momen pada saat pemberlakuan PSBB yang cukup ketat di tiap-tiap daerah yang menjadikan masyarakat cenderung aktif untuk berbelanja online. Keadaan inilah yang tentunya dimanfaatkan oleh banyak pelaku usaha dari lini bidang kecil, menengah hingga atas untuk mulai memikirkan cara agar tetap dapat menjangkau para konsumen. Dalam hal ini platform e-commerce yang sebelumnya belum booming seperti saat ini dimanfaatkan oleh mereka para pemilik usaha. Permasalahan ekonomi yang timbul selama masa pandemic memberikan sebuah pola baru dalam masyarakat, bahkan dalam hal berbelanja. Masyarakat diberikan pilihan untuk tetap berbelanja atau menabungkan uangnya karena adanya permasalahan ekonomi. Namun ada juga masyarakat yang tetap memilih berbelanja untuk memenuhi kebutuhannya, atau bahkan untuk membantu perekonomian bangsa (Afrianto, 2021).

Bentuk-bentuk perubahan yang terjadi di aktivitas jual beli sekarang ini merupakan salah satu bentuk perubahan sosial. Ada banyak yang mendefinisikan perubahan dalam arti yang luas. Wilbert More misalnya mengartikan perubahan sosial sebagai suatu perubahan penting yang terjadi dalam keseluruhan struktur sosial, pola-pola perilaku, dan system interaksi sosial, termasuk di dalamnya perubahan norma, nilai, dan fenomena kultural (Goa, 2017).

Menurut William F. Ogburn perubahan sosial mencakup unsur-unsur kebudayaan baik material maupun immaterial yang menekankan adanya pengaruh besar dari unsurunsur kebudayaan material terhadap unsur-unsur immaterial. Adanya pemanfaatan teknologi dalam aktivitas jual beli akan mempengaruhi pola tindakan pembeli.

Akibat dari perubahan sosial yang terjadi dalam proses jual beli tersebut tidak dipungkiri akan melunturkan entitas dari aktivitas penjualan itu sendiri. Sifat ketradisionalan dan substantif perlahan akan berubah menjadi sifat yang menekankan pada hubungan relasi secara formal seperti halnya pada system pasar modern. Pada akhirnya perubahan yang terjadi pada aktivitas jual beli secara konvensional harus melalui kajian yang matang. Sehingga penjualan secara konvensional tidak kalah bersaing dengan penjualan secara digital tanpa harus kehilangan ruhnya. 


\section{Kesimpulan}

Perubahan sosial dalam masyarakat bukan merupakan hasil atau produk melainkan suatu proses. Proses perubahan ini tentu saja merupakan hasil dari suatu kesepakatan atau keputusan bersama yang diambil oleh individu atau suatu kelompok masyarakat. Keputusan yang diambil tentu saja yang sesuai dengan keinginan atau harapan kelompok agar perubahan sosial dapat terwujud. Ekonomi dan budaya merupakan suatu masalah pokok yang terjadi dalam kehidupan masyarakat dewasa ini. Dengan kemiskinan dari segi ekonomi ini dapat mempengarui kehidupan masyarakat seperti perilaku sosial, cara berpikir, bertindak, dan lain sebagainya. Ekonomi dapat menyebabkan masyarakat menjadi hidup dalam kemiskinan.

\section{Daftar Pustaka}

Afrianto, A. P. (2021). Eksplorasi Kondisi Masyarakat dalam Memilih Belanja Online Melalui Shopee selama masa Pandemi Covid-19 di Indonesia. Jurnal Teknologi Dan Informasi Bisnis, 3(1).

Andi Maghfirah Juniar, J. (2021). Belanja Online di masa pendemi covid-19: studi kasus ibu-ibu rumah tangga di Makasar. Jurnal E-Mik, 4(1).

Awy Apriani Ningrum Simamora, M. F. A. (2019). Kemudahan aplikasi dan keberagaman produk dalam membentuk keputusan pembelian generasi milenial berbelanja secara online. Maneksi, 8(2).

Bagus Ardiansyah, Drajat Tri Kartono, A. D. (2019). Dromologi dan Era Flash Sale: Tinjauan Geliat Manusia dalam Cyberspace. Simulacra, 2(2), 115-131.

Budiyono. (2015). Fenomena komunikasi politik dalam media sosial. Iptek-Kom, 17(02).

Catriana, E. (2020). Aktivitas belanja online meningkat drastis, inilah sebabnya. Kompas.Com. https://www.google.com/amp/s/amp.kompas.com/money/read/2020/10/27/1358 47026/aktivitas-belanja-online-meningkat-drastis-ini-sebabnya

Dedy Ansari Harahap, D. A. (2018). Perilaku belanja online di Indonesia: Studi Kasus. Jurnal Riset Manajemen Sains Indonesia, 9(2).

Editor. (2018). Digitalisasi Bisnis di Era revolusi industri 4.0. Qlausa.Com. https://www.qlausa.com/digitalisasi-bisnis-di-era-revolusi-4-0/ 
Editor. (2020). Kenapa Pesta Belanja Online Semakin Marak? Ini Alasannya. Sirclo.Com. https://www.sirclo.com/kenapa-pesta-belanja-online-semakinmarak-ini-alasannya/

Goa, L. (2017). Perubahan Sosial dalam Kehidupan Bermasyarakat. Jurnal Kateketik Dan Pastoral, 02(02).

Hidayat, Z. (2015). Dampak Teknologi Digital Terhadap Perubahan Kebiasaan Penggunaan Media Masyarakat.

Nugroho, A. (2019). Pengertian E-commerce dan Perkembangannya di Indonesia. Qwords.Com. https://qwords.com/blog/pengertian-e-commerce/

Nur Indah Ariyani, O. H. N. (2014). Digitalisasi Pasar Tradisional: Perspektif Teori Perubahan Sosial. Analisa Sosiologi, 3(April), 1-12.

Pradoko, S. (2017). Paradigma Metode Penelitian Kualitatif. UNY Press.

Prinada, Y. (2021). Apa saja ciri-ciri perubahan sosial dan contohnya dalam masyarakat? Tirto.Id. https://www.google.com/amp/s/amp.tirto.id/contohperubahan-sosial-di-kehidupan-sehari-hari-masyarakat-desa-gbRv

Rozi, H. S. \& F. (2020). Belanja online dan jebakan budaya hidup digital pada masyarakat milenial. Simbolika, 6(2).

Shobirin. (2015). Jual beli dalam pandangan Islam. Jurnal Bisnis Dan Manajemen Islam, 03(02).

Sumarno Adi Subrata, M. V. D. (2017). Puasa Ramadhan dalam Perspektif Kesehatan: Literatur Review. Khazanah: Jurnal Studi Islam Dan Humaniora, XV, 235-256.

Susiawati, W. (2017). Jual beli dalam konteks kekinian. Jurnal Ekonomi Islam, 08(02).

Yanti, I. (2018). Pengertian Jual Beli. Jejakpendidikan.Com. http://www.jejakpendidikan.com/2018/10/pengertian-jual-beli.html?m=1 